\title{
"Roma" Label: The Deconstructed and Reconceptualized Category within the Pentecostal and Charismatic Pastoral Discourse in Contemporary Slovakia
}

\author{
Tatiana Podolinská
}

Institute of Ethnology, Slovak Academy of Sciences

\begin{abstract}
This paper deals with the ways of reconceptualization and negotiation of a new ethnicity and identity within the Pentecostal and Charismatic pastoral discourse among the Gypsies/Roma of Slovakia. The analysis is based on three denominations: the Word of Life movement in Plavecký Štvrtok, the Maranata Christian Mission in Spišská Nová Ves and the St. Paul's Community within the Greek-Catholic Church in Čičava. The comparative analysis of pastoral and converts' narratives has shown that the "New Roma" category is constructed as an ahistorical category of practice, which is intentionally largely ethnically emptied and creatively filled with specific content according to the life goals and paths of particular users either at the individual level or at the community level in line with the creed of good, moral, useful and decent life (of a Christian $=$ Human $=$ Rom). Research has revealed that in spite of the strong trans-social and trans-ethnic discourse, according to which believers should lose the reason for taking into account the inter-group stratifications, they still remain ethnically and socially sensitive. An important change in this context is, however, that the previous paradigm Gypsies versus "Whites" turns, after conversion, into the paradigm Roma alongside other nations. This fundamentally changes the basic classificatory schemes and positional way of defining themselves in relation to others. The New Rom is primarily the negation of the Old Rom, not of the WhitelGadjo. The way in which Pentecostal and Charismatic pastors positively reconstruct, reconceptualize and negotiate the "New Roma" identity at the individual, group, collective and national levels goes largely beyond the traditional (modern) perception of ethnic identities and does not take into account historical origin, country, language, culture, etc. as constitutive elements. From this viewpoint, the Pentecostal and Charismatic pastors operating among Gypsies/Roma in contemporary Slovakia would be considered to be engineers, mentors and tutors of ethnoreligious innovation
\end{abstract}

\footnotetext{
* Tatiana Podolinská, Institute of Ethnology, Slovak Academy of Sciences, Klemensova 19, 81364 Bratislava, Slovak Republic; tatiana.podolinska@savba.sk

This article is the output of a scientific project directed by the author and funded by the Slovak national Scientific Grant Agency VEGA 2/0099/15, entitled "Label Roma - its emic and etic reflections and social impact". I am grateful to the anonymous reviewers for their useful and appropriate comments on this article. I also appreciate the comments and feedback of Bill Baker, and for the sensitive proofreading, I am grateful to Ruth Zorvan.
} 
based on the concept of relocation and accommodation of Gypsies into the new and positively reconceptualized label Rom/a.

\title{
Keywords
}

ethnicity and identity studies; classificatory schemes; Romani Studies; label Rom/Roma; Pentecostal and Charismatic movements in Slovakia

\section{Introduction}

\begin{abstract}
My first contact with Slovak Pentecostalism ${ }^{1}$ among the Gypsies/Roma was in 2003 via Greta, a Gypsy² woman in her middle ages living in Plavecký Štvrtok, a small village in the Western part of Slovakia. At that time, I was conducting my participative observation research on the socially diverse and extremely
\end{abstract}

\begin{abstract}
1 The name of the Pentecostal movement comes from the Greek pentekosta $=50$; the original holiday "Pentekostes" in the Christian tradition is called "Whitsun" (or "Turíce" in Slovak), which refers to the culmination of the 50-day period from Easter marked by the "pouring out of the Holy Spirit", which was manifested, among other things, by "speaking in many languages" (Sk2, 1-11). Pentecostalism is a broad current of enthusiastic Christianity, which appeared at the beginning of the 20th century in the US. It places emphasis on the use of exceptional spiritual gifts (charismas) in the life of a Christian and is manifested as a "foray" of a new way of life ("rebirth", "awakening"). The Pentecostal movement (specifically, its Protestant part) understands sanctification as a one-time event to be followed by a qualitatively different Christian life. Its followers use the term "baptism in the Holy Spirit" for this event and understand it as an inevitable experience in the life of a Christian. According to Pentecostal understanding, "reborn" Christians express themselves with missionary activities and charismas, like speaking in tongues (glossolalia), the gift of prophecy, healing, doing miracles, etc. The Pentecostal movement developed gradually in three waves: as the Whitsun movement, as the Charismatic movement (denominated within the Catholic Church as Rebirth in the Holy Spirit Movement, and, finally, as the neo-Pentecostal (neo-Whitsun) movement or the Movement of Belief (Theology of Prosperity). Even today, it is marked by massive expansion all over the world. Within this wide-spectrum Charismatic current, there are, e.g. the Apostolic Church and the Neo-Apostolic Church in Slovakia, as well as many other Christian groups registered as civic associations (e.g. Christian Communities, the Grace community, the Word of Life, Open Doors and many others). For the activities of the Pentecostal churches among the Roma in Europe, see footnote 9 in Podolinská 2003, 28-29.
\end{abstract}

2 We have to be aware that the term "Gypsies" used in English is not quite accurate in the case of Slovakia. In the region of Central Europe, the term "Gypsies" is frequently used to translate the ethnonym Cigáni into the English. In our region, the word Cigáni was used for centuries to designate separate, clearly defined ethnic communities with common origins, as a sort of umbrella term for a heterogeneous community (Marushiakova, Popov 2013, 62). Nowadays, it has clearly pejorative connotations and is used in public discourse as a sort of general invective, as "cigán/cigánit" means in Slovak language "a liar/to lie". In order to prevent the usage of the pejorative ethnonym in public discourse, the newly coined term Rómovia ("Roma") is currently being promoted as a neutral term. I recognize the term Roma as a politically correct umbrella term. Nevertheless, I take the view that in the research of ethnicity, identification and self-identification of ethnic groupings is important; that is why I will use the original (ethnic) label Cigáni translated here as Gypsies, for retaining the original context as much as possible and the term "Roma" as the translation of the label Rómovia as integral parts of quotations from pastoral or converts' narratives, or again, for retaining the original context in the places where this term is used as reconceptualized meta-term in connection with the pastoral concept of "New Roma". In the remainder of my article, in order to distinguish wider exo- and endodiscourses, I will use "Gypsies" as the content-neutral umbrella term. So, my usage of the word Gypsies is fitting with the "Gypsy II", as described by Matras (2004, 55-6). 
polarized Gypsy community, members of which lived in a segregated part of the village named Kolónia ("Colony"). ${ }^{3}$

Greta was living as a guardian in the renovated part of the former kindergarten situated on the borders of the "White" village and "Gypsy" Colony. At that time, I was researching the social impact of Pentecostal conversion on Gypsies. It was during the long spontaneous discussions with Greta that I first realized how her conversion to the local assembly of Word of Life and getting familiar with pastoral discourse made her not only to radically emancipate her "Gypsiness" but also to deconstruct the general categorization of people and to rethink the hierarchic asymmetries based on ethnicity. She informed me, with a peculiar mix of conspiracy, confidence and humor, that the Virgin Mary and Jesus could not have been white like me (I was considered a representative of the white majority). Instead, she believed, that the Virgin Mary must have been like her, with curly dark hair, brown eyes and dark skin. When describing the dark skin of the Virgin Mary and of herself, she used a very interesting adjective: "chocolate" (more in Podolinská 2014a). It was still a dualistic concept, a kind of a modification of the black/brown and white categorization; nevertheless, the association of "chocolate" that she used in connection with the Jesus, Virgin Mary and herself was clearly a sign of her private attempt to connect the label "black/brown" (Gypsy) with (irresistible) positive content ("chocolate"). During the interview, she was very coherent in using this "chocolate" association: "The God had the idea, I will make Tanya (i.e. the author of the study) white, whereas Greta, I will make her chocolate". She was very critical of "black" and "white" negative ethnic and racial stereotypes and stressed the value of cultural and ethnic differences: "We are equal but not the same!" she asserted.

After days of being with Greta and continuing my research both with converts and nonconverts in the Colony, I started to trace the impact of conversion on basic classificatory schemes, inter-group hierarchies, redefinitions of vectors of power and especially the work with ethnic labels Cigáni ("Gypsies"), Rómovia ("Roma")" and Gadžovia/Bieli ludia ("Gadje/White People" in individual and group narratives.

I recognized that local Gypsy nonconverts insisted on the imagery of World as unfair but done as such and given forever. They relied on basic dualistic categorization of people to Bieli ("Whites" as They-Group) versus Cigáni

\footnotetext{
3 A settlement of sedentary Gypsies with no internal notion of belonging to any Gypsy subethnic group, using the local Slovak dialect as their mother tongue and with only a few Romani words in practical vocabulary. Only elderly people retain passive knowledge of the Romani language.
} 
Picture 1. Mural of Virgin Mary painted on the kitchen wall, inside of the Roma household in Vysny Slivnik (anonymous Roma author). Detail of the mural inspired by the small Catholic leaflet depicting the Holy Family shows that author portrayed the Virgin Mary of dark skin (not mechanically copying the white skin of Madona at original picture). (Author of the photography: Tatiana Podolinská, 2006.)

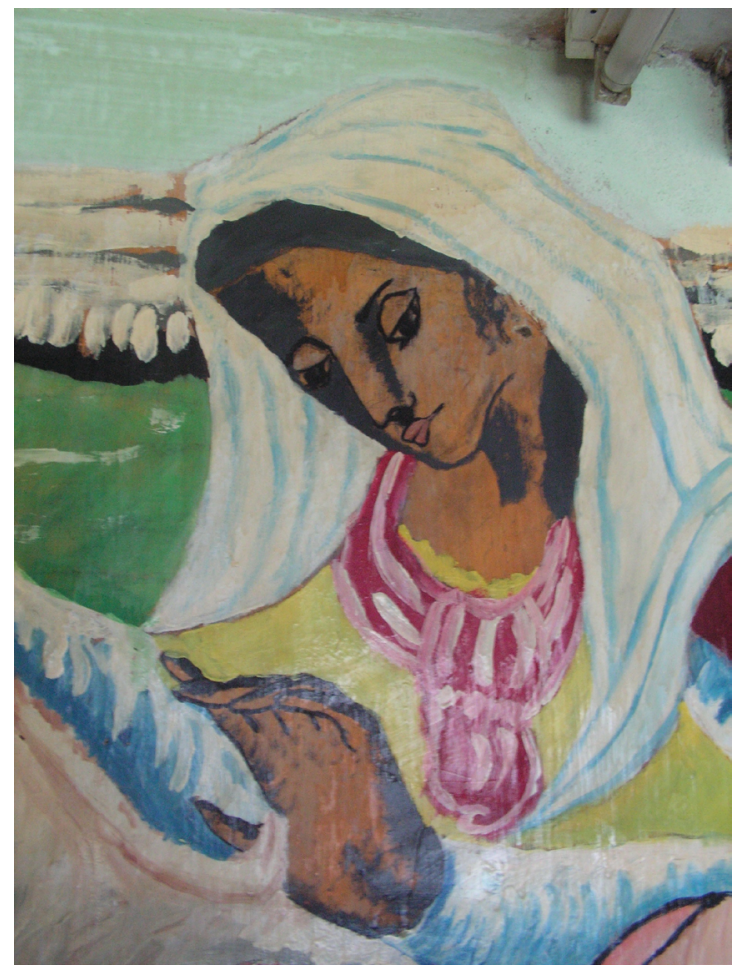

("Gypsies" as We-Group), ${ }^{4}$ considering them to be ethnically or even racially different groups of humankind with specific qualities embedded in every member of each respective group. In their understanding, the World into which they were born and have to live their Gypsy life was determined by predefined hierarchical asymmetries and settings of power disbalance in favor of non-Gypsies with almost no possibility of change. According to them, these two groups of people were in dialectic opposition, Gypsies contralversus non-Gypsies, and vice versa.

4 On the imagery of "We-Group" and "They-Group" and an extensive discussion on primordialism in ethnicity and identity in the Slovak context, see the article by Viera Bačová (1998, 29-43). 
Local Gypsy converts, on the other hand, getting familiar with pastoral trans-ethnical and trans-social discourse, have adopted ethnically and racially deconstructed classificatory schemes of people. In their convert narratives, they claimed to divide people into Converts, i.e. "progressive Roma" alongside "non-Roma" (as the We-Group) versus Nonconverts (as They-Group, by which they first of all meant nonconverted Gypsies from the Colony but also members of other denominations and churches in general).

Based on my observation of the life within the Colony and the mutual local intra-group Gypsy-Gypsy relationships, despite the trans-ethnic discourse spread by the local pastor, Gypsy converts still retained their "ethnic lenses" and stayed ethnically and socially sensitive. In fact, they used conversion to clarify the social distance between Themselves and nonconverted Gypsies, whom they considered to be "second class" Gypsies (in the discussions, they frequently called the latter "dirty and backward Cigáni"). In order to skip from this ethnic label with negative connotations, they themselves adopted the ethnonym Rómovia ("Roma") and its positive content offered by the pastor. In their understanding, it was a sort of transnational umbrella term for all Roma diaspora living in Europe. In their narratives, they claimed to be proud of and identified with this term. They also claimed to declare the Roma ethnicity in official censuses (Podolinská 2003).

Being in the field, I was repeatedly told of the direct and strong impact of entering into and practicing the Word of Life in the Colony on the local Gypsy-Gypsy constellations and the deepening of the mutual intra-group animosities within the local Gypsy community. Considering the local situation and the local community as a specific and maybe unique case, I was lucky to design multi-sited research on the social impact of conversion on Gypsies/Roma in Slovakia (project SIRONA 2010). ${ }^{5}$ During the project, I continued my previous research conducted in Plavecký Štvrtok, and I started to work with two more and very different communities in the Eastern part of Slovakia. During my research, I focused on looking for patterns and the impact of Pentecostal/Charismatic conversion on coping with Romaness/Gypsiness, as well as its positioning within the mainstream population world.

From that time, I started to trace not only the individual converts' and nonconverts' narratives, but I also focused on research into pastoral discourse and narratives, which I supposed to be the main engine of the

\footnotetext{
5 Project funded by the European Social Fund, entitled Social Inclusion of Roma via Religious Way (SIRONA 2010) was conducted in 15 localities in Slovakia in 2010. For a report in English, see Podolinská and Hrustič (2011).
} 
deconstruction of previous classificatory schemes, mostly based on ethnic and racial stereotypes. I tried to also trace the mirroring of sophisticated pastoral discourses in individual converts' narratives to understand slight shifts within personal interpretations in accordance with one's life experiences and track records.

In this paper, I will summarize my findings based on my field work research, which has been centered for $>14$ years on Pentecostal and Charismatic movements, their pastoral discourse and activities among Gypsies/Roma in Slovakia. I will also apply some vividly discussed theoretical concepts ranging from the field of social and cultural anthropology and social theory to Romani Studies. More precisely, I will focus on the recent debates about the identity and ethnicity discourse and discuss their potential ethical and practical consequences. The main body of the study will be focused on tracing the processes of the deconstruction of the ethnic category Rom/a, its reconceptualization as a vacant label within the narrative of change and the consequent "positive" filling within the Pentecostal and Charismatic pastoral discourse in Slovakia as an example of a more general process of ethnoreligious innovation within the European Gypsy Pentecostalism as such. ${ }^{6}$

\section{Social Theory Inspirations}

The Norwegian ethnographer Thomas Hylland Eriksen pointed out in his famous work Ethnicity versus Nationalism (1991) that ethnicity refers to the social reproduction of basic classificatory differences between categories of people and to the aspects of gain and loss in social interaction (Eriksen 1991, 264). Despite the existence of multi-ethnic societies and communities within modern states, we can identify the idea of "state nationalism", which is symbolically linked to the collective identity of only one of the populations. Eriksen (1991, 263-4) distinguishes between nationalistic ideologies (tendency to promote cultural similarities and wide-ranging integration of all the inhabitants of the nation-state, regardless of their ethnic membership) and ethnic ideologies (tendency to promote cultural diversity and autonomy within the home state). According to him, the necessary condition for peaceful coexistence of multi-ethnic populations within a nation-state entails also the right to be different, the right not to participate in national society in certain respects.

6 In this context, also refer the article of Manuela Cantón-Delgado $(2017,87)$ and her interpretation of Gypsy leadership and new forms of internal cohesion within the Evangelical Church of Philadelphia in Spain as "innovation". 
Judged on this criterion, ethnicity can sometimes be interpreted as a form of stagnant nationalism, which may eventually, or periodically, become manifest as nationalism (Eriksen 1991, 265) Eriksen (1991, 266) states that "the nation is an invention; [...] to paraphrase Anderson [1983], it is an imagined community; it is not a natural phenomenon, despite the fact that the object of all nationalism is to present a particular image of society as natural".

In this regard, the concept of American sociologist Rogers Brubaker is still extremely inspiring; he observes in what way we treat the categories of ethnicity and identity in common practice and in the political, scientific and media discourse. In his famous work Ethnicity without Group (Brubaker 2002), he goes even further in his criticism of the mixing of common and analytical language and strongly criticizes the term "group", which was taken for granted in the study of ethnicity, race and nationhood. In his studies, Rogers Brubaker (2002, 162-163) operates with the term groupism which, according to him, is a tendency to treat ethnic groups, nations and races as substantial entities to which interests and agency can be attributed. It is a tendency to treat group (ethnic or religious one) as real, substantial things-inthe-world.

Brubaker insists that we as scientists cannot uncritically adopt categories of ethnopolitical practice as our categories of social analysis. Instead of doing that, he appeals, we have to rethink ethnicity - in relational, procedural, dynamic and eventful terms: “...thinking of ethnicity, race and nation not in terms of substantial groups or entities but in terms of practical categories, cultural idioms, cognitive schemas, discursive frames, organizational routines, institutional forms, political projects and contingent events" (Brubaker 2002, 167).

According to Brubaker (2002; 2014), ethnicity should be studied as a category of practice, thus applying a nongroupist approach, i.e. it should be observed and described from a dynamic perspective at a concrete level as the agenda of concrete actors (organizations, political parties or leaders, activists, etc.). In this context, let me offer the reader a short overview of how ethnicity and Gypsy/Roma identity are approached and even constructed within the Romani Studies.

\footnotetext{
7 Besides "traditionally" highlighting the fact that we cannot approach groups as real entities and expect from them a real agenda, he also points out that national identity should be approached as an institutionalized form. According to him, national awareness is the result of the events principle, and nation should therefore be viewed as a category of practice (Hroch [ed.] 2003, 375-385).
} 


\section{Current Discourse on Ethnicity and Roma Identity within the Romani Studies plus an Open Discussion}

Throughout the past period of $>40$ years, we can notice - in the literature on Romani Studies - a number of attempts by several authors to explain the extreme diversity of Roma/Gypsy social norms and ways of behavior, as well as their ability to resist and preserve (the local forms of) "Romahood" in very different majority societies under very different conditions. In the present-day scientific literature, we can distinguish between several main approaches, schools and their main representatives according to their ways of conceptualization of Roma identity.

In his summary study, Michael Stewart (2013, 415-432) identifies three basic ways of explaining otherness and the resistance of Gypsies/Roma in anthropological literature: (1) historical, (2) socio-structural and (3) cultural. According to Stewart, the historical line explains the internal differences within Gypsy/Roma groups by their historically different origins and their resistance within majority societies by their different ethos of a foreign ethnic group, which does not allow assimilation in another culture and social mode. He mentions Anne Sutherland and Yaron Matras as examples of authors who were inspired by this approach (Stewart 2013, 418). Stewart defines the structural line as a current, viewing Gypsies/Roma as a group that flexibly occupies the free social and economic niches within the historically changing Europe, while responding actively and using the institutions and states into which it moves. Besides himself, he also lists J. Okely and M. Olivera as the main representatives of this approach. The cultural approach assumes internal coherence of the system of values within diverse sub-ethnic Gypsy/Roma groups (Stewart 2013, 418).

A frequent criticism of academicians of Romani Studies is that they are using a homogenizing discourse. This corresponds with Brubaker's general criticism of groupism, tendency to apply "group lenses", to homogenize heterogeneity, thus creating groups (on the base of ethnicity, culture, socio-economic status or the way of life) which are supposed to be entities with common and shared quality (identity). To highlight the heterogeneity of Roma minorities, describing them as a diaspora forming "a mosaic of small diverse groups" (Liégeois 1986, 49) ${ }^{8}$ might not seem enough. Some authors have called for bringing hybridity to heterogeneity in Romani Studies (Tremlett 2009), while others have directly accused Romani Studies of essentialism and ethnic

\footnotetext{
8 Nevertheless, it is questionable whether this approach is effective enough to break away from homogenizing terms and whether it is still not a case of the groupist approach; the concept of diaspora implicitly works with unity and homogeneity beyond the heterogeneous parts.
} 
absolutism, producing the image of the "true Gypsy". Social historian Win Willems, in his book In Search of the True Gypsy (1997), argues that academics are continuing the circulation of false or exaggerated representations (Tremlett 2009, 148). As a response, some authors see his work as denying the subsequent important scientific finds of the Indian origins of Roma people (e.g. Matras 2004), others are concerned he is deconstructing Roma identity into nonexistence (Acton 2004, 113-5).

As a sort of open discussion, I would like to offer some comments on the present-day controversies among Romani Studies' academics and the general social theory and anthropology and (potential) ethical and practical consequences of adopting the approach of speaking beyond the "ethnicity" and "groups" at all.

(a) Influenced by the general social studies theory, the deconstructivists' approach has also been introduced within Romani Studies (deconstruction of the idea of Gypsies as an "ethnic group", deconstruction of the idea of "cultural idiom"10), followed by attempts on how to reconceptualize Gypsiness as a "way of being" (Gay y Blasco 1999, 176), and so on. The methodological approach aimed at decontamination of ethnic and racial studies from essentialism and primordialism, ${ }^{11}$ however, contains the thread of some (potential) methodological blindness: This leads to the question of whether any attempt at describing or representing ethnic groups inevitably results in some kind of essentializing frame. In this regard, Hall's work on antiessentialism aimed at reconceptualization of ethnicity without relying on biological or cultural essentialism might provide the navigation. He conceptualized "new ethnicity" as something not stabilized by Nature or by some other essential guarantor $(1996,446)$. In his understanding, it is more the question of talking about experience. According to Hall (1996, 447), it is not possible to skip from the ethnicity, because we are all "ethnically located and our ethnic identities are crucial to our subjective sense of who we are". This corresponds also with Eriksen's (1995) notion on ethnicity, as a

9 One of the major theoretical challenges in Stewart's work is the rather controversial proposition that Gypsies are not an "ethnic" group in the sense of an "inherited past", but rather "for them, identity is constructed and constantly remade in present in relations with significant others" (Stewart 1997, 28).

10 Hungarian sociologists Ladányi and Szelényi $(2003,50)$ argue that Stewart's conceptualization of "cultural Rom" serves only to create the idea of an "eternal Roma", which does not take into account historical positioning according to socioeconomic status.

11 In the context of essentialism, ethnic absolutism, antiessentialism and new ethnicities as the possible approach to ethnicity without denying but, rather, as a reconceptualized and renegotiated issue, see the works of the authors within the British Cultural Studies (BCS): Hazel Carby, Paul Gilroy and Lawrence Grossberg (Tremlett 2009, 160). 
frame that offers people most of their social statuses, in the context of overall cultural identity being formulated by means of ethnic idioms.

(b) The accentuation of the process of the social construction of "Romahood" and Roma ethnicity and the highlighting of the fact that it is not about primordial entities or ontologically objectively existing entities and that, at the ethical level, they should be treated in the context of abstract or imagined communities (Anderson 1983) does not automatically mean that we "deprive them the right of existence", i.e. that we are not aware of their social and practical "existence". In fact, these concepts/constructions, without exaggeration, control a substantial part of social behavior; people categorize, accept categorization schemes and subsequently behave and act on the basis of these categorizations, thus perceiving the "We-Group" and the "They-Group" as ontological entities (Eriksen 1995; Brubaker 2004). As social scientists, we have to take into account and respect social praxis and take responsibility for our discourse, also considering carefully the potential impact and risk of misunderstandings or content shifts during the process of dissemination or popularization.

(c) Finally, it is necessary to emphasize that the "We" and "They" categories in social praxis are not only seen in primordialist imagery, they are ascribed also a qualitative and moral dimension on the basis of the asymmetric or directly dualistic principle. In this way, the category "I"/"We" (mine/ours) often merges with the perception of the category of (the only) good, correct, nice and normal.

(d) When speaking about Gypsies in Central and Eastern Europe, we cannot omit the historical and contemporary contexts of ethnopolitical praxis, which are different from those in Western Europe. Without explaining, that - for instance - the group of Slovaks is the same social artifact and imagined community as the group of Roma, we as scientists would easily foster existing racist public discourse. Speaking beyond the ethnicity, culture and group in the case of Gypsies/Roma in Central and Eastern Europe may cause their further marginalization and invisibilization in public space (Podolinska 2017). In order to prevent such misunderstanding, academics such as Elena Marushiakova and Vesselin Popov $(2016,3)$, in their latest book, come up with the proposition to see "Roma ethnic culture as a phenomenon of the same order with the ethnic cultures of all other European nations, with whom the Roma in Eastern Europe live together". They claim that, in Central and Eastern Europe, the criterion of who the Roma are is, above all, a matter of ethnic origin, regardless of social status or cultural characteristics. According to them, it would be unrealistic to expect that in an attempt to build their 
identity, the Roma of Central and Eastern Europe should radically differ from the general ethnonational pattern characteristics for this part of Europe since the middle of the 19th century.

(e) In the political and, unfortunately, in the scientific discourse as well, we face forced (nonnatural) ethnicization of the categories "Romahood", Rom/a and the Roma nation. From this point of view, the traditional (modern) type of ethnicity (based on traditional definitions of the nation) is often intentionally overcommunicated. Likewise, we can encounter intentional undercommunication of this topic. Both ethnicization (excessive accentuation of the ethnic perspective) and de-ethnicization (its intentional suppression) usually serve as practical (political) tools for an objective fixing of the unfavorable or unequal position of this ethnic minority not only within particular ethnonational European countries but also at the supra-national European level.

\section{What Does It Mean To Be A Rom? Pentecostal and Charismatic Pastors As Ethnoreligious Innovators}

The Pentecostal and Charismatic pastors operating among Gypsies in Slovakia are also facing the same problems as the social scientists dealing with Gypsies/Roma at various levels, using various approaches and methodologies in deconstructing and constructing the category Rom/a. Their challenge is how to (successfully) accommodate and operationalize the general pastoral discourse and theology into local common discourse and social praxis, facing the life experiences not only of their Gypsy adherents but also their nonconvert and non-Gypsy neighbors.

Pentecostal and Charismatic churches would not seek to act as mediators between different ethnic groups but offer a sort of "brubakerian" solution beyond any ethnic ascriptions: ethnic groups are ascribed diversity, but before God, all are equal.

Nevertheless, according to the pastors I was in contact with, the situation in Slovakia does not allow them just simple application of general transethnic discourse. Trans-ethnicity would simply not work without sensitive and complex work with their Gypsy clients' identity and ethnicity. According to their narratives from the beginnings of their pastoral work in Slovakia, ${ }^{12}$ they started to work with people with zero self-esteem, stuck to live in/with the stigmatized ethnolabel Cigáni in a destroyed social infrastructure on the margins of mainstream society, relying only on the social welfare system,

\footnotetext{
12 I can rely here only on their narratives because I have never had the possibility to be present at the establishing of the new branch or daughter assembly; I always entered into the field of an alreadyestablished congregation.
} 
Gypsy loan sharks and small private family networks of close relatives sharing and reproducing the everyday know-how of how to cope with extreme poverty with no vision and technique of how to get out of it.

Pastors in Slovakia have to cope not only with extremely negativist (racist) image of the ethnolabel (used also as umbrella endoethnonym) Cigáni based on ethnic and cultural negative stereotypes but also with the fact that the label Rómovia, introduced in the second half of the past century in official documents as a neutral one, is nowadays to a large extent "contaminated" in public media and even political discourse with prejudices and negative characteristics as was the former label "Cigáni"'3 (Mann 2015, Krekovičová 2015, Panczová 2015, Podolinská 2017).

In connection with the faster-increasing demographic growth index of the Roma population, constantly accentuated by the media, ${ }^{14}$ and the image of their (alleged) inability and unwillingness to adapt to the standards of the majority society, the overethnicized and essentialized label "Rom" is becoming not only unattractive but also extremely stigmatizing. ${ }^{15}$

In this context, the most crucial questions that Pentecostal and Charismatic pastors operating among Roma are confronted with on a daily basis are the following: "What does it mean to be a (good) Rom?" Or better said, "a Rom enjoying respect (by a Rom and wider society too)?"

In this study, I will trace the work with the ethnic categories of Rom/a in three selected denominations in Slovakia. Through a comparative analysis of the pastoral and converts' narratives, I will follow how it is programmatically deconstructed and consequently constructed based on new principles as a category of practice, as a largely ethnically "vacant" category that is creatively filled with particular content according to the life goals and trajectories of specific users, either at the individual level or at the group and community levels, in line with the creed of good, moral, useful and decent life (of a Christian $=$ Human $=$ Rom). In addition to the pastoral discourse concerning

\footnotetext{
13 Among the general population, the ethnic label "Rom" is generally associated with many negative prejudices and stereotypes ascribed to the group as a whole. The most common ethnical stereotypes include images of a priori negative attitudes to work, which result in accusations of the misuse of the social system and (voluntary) life strategy of living from social benefits, high fertility rate, inappropriate sexual behavior, including family incest, poor hygiene and education, reduced intelligence skills and high crime (for more details, see Mann 2015, 438-479).

14The recent demographical trends in Slovakia suggest that while the mainstream population has 1.51 children per family, it is 4.2 children per family among the Gypsy population (Vašečka 1999).

15 In spite of the fact that the estimated share of the Roma ethnic group in the total population is $7 \%-$ 8\% (Mušinka and Matlovičová 2015, 232-233), thus representing the second most numerous ethnic minority in Slovakia, in the last Census, only 2\% of inhabitants declared the Roma ethnicity (105,738 people) (Statistical Office, Census of People, Houses and Inhabitants 2011).
} 
the personal, lived category of Rom ("Romahood" from the private perspective), I will also observe the way of construction of the collective/ group, as well as ethnically perceived category of the "Roma nation", at the national and supra-national levels.

\section{Research Sample}

My analysis is based primarily on my own field research at various locations in Eastern and Western Slovakia, marked by the presence of various Pentecostal denominations of Whitsun and Charismatic nature among the Roma. In Slovakia, they form part of "nonregistered churches/movements", and most of them work officially as civic associations, while carrying out a whole range of nonreligious activities. I will base my work primarily on the analysis of the pastoral discourse and conversion narratives from within the Charismatic movement Word of Life in Plavecký Štvrtok in the West of Slovakia, $40 \mathrm{~km}$ from Bratislava. Here, with some interruptions in work, the assembly of Word of Life has been operating for almost 2 decades, so one can also find the second generation of adherents here. The second part of my research I am relying on here is based on research on the Pentecostal movement Maranata, which has been operating in the East of Slovakia in the vicinity of cities Spišská Nová Ves and Poprad for $>10$ years. The third denomination presented here will be the Charismatic assembly of the Community of Paul the Apostle within the Greek Catholic Church in Cičava. Before the analysis itself, I will shortly describe the context of the localities, the history of the assemblies and the work of their pastors.

\section{The Word of Life - Plavecký Štvrtok}

The Word of Life movement was founded in Sweden in 1983. In the same year, Ulf Ekman, the founder of the movement, established the Biblical School in Uppsala. The school was attended by students from Scandinavia and later from all over Europe. In the 1990s, the school began to carry out missionary work mainly in the countries of the former Central and Eastern European socialist bloc. The first missionaries of the Word of Life began arriving in Slovakia at the end of the 1980s, shortly before the fall of the Communist regime. The movement gradually established closer cooperation with the church in Uppsala and with believers from Brno and the Water of Life from Prague. The Biblical School for Central Europe opened in 1994, having trained the first generation of professional leaders. One of the main founders of the Word of Life in Slovakia was Peter Čurík, who has been the chief pastor 
since 2002. ${ }^{16}$ In the past, the Word of Life was also active among Gypsies in Eastern Slovakia, namely near Sobrance and Michalovce. It conducted its activities under the leadership of Pastor Ján Vihonský in 1997-2002. ${ }^{17}$ In spite of its initial success, it withdrew from its activities in Eastern Slovakia. Since the mid-1990s, non-Roma pastor Milan Juríček has been carrying out missionary work in the Gypsy settlement of Plavecký Štvrtok.

The Gypsy population in Plavecký Štvrtok is around 600. Most of them live segregated in the part of the village called Kolónia (Colony), which is one of the few segregated Gypsy settlements in Western Slovakia. Most Gypsies living in this settlement are unemployed and receive social benefits, but the vast majority of them can live very decently thanks to undeclared occasional and seasonal work (men) and the picking of forest berries, mushrooms, needles and mistletoe (women). The prevailing denomination in the municipality is Roman Catholic, though the local priest does not conduct any special activities within the Gypsy community. Salesian women have been active among the Gypsies in Plavecký Štvrtok for many years and have been running a "Leisure Centre for Roma children", together with the Ad Patrem Civic Association. Besides Salesians, members of many other religious communities have also been active there, especially the Sisters of Mother Theresa, as well as Redemptorists, Verbits or Franciscans, and today also the Apostolic Church. In 1995, Milan Juríček, formerly a member of the Apostolic Church, bought a rundown building of a former kindergarten located on the outskirts of the settlement. He reconstructed the building with the help of the local Gypsies and began to lead a religious mission under the auspices of the Word of Life, Modra. For the running of the Social Prevention Centre, Milan Juríček obtained funds not only from the United Dutch Foundation and the Government Office of the Slovak Republic, but he also invested the money from his own private car service in Modra and later the funds of his association, which, at the beginning, also ran cobblestones manufacturing and medicinal plant harvesting. ${ }^{18}$ None of these initial activities are run anymore. Juríček initially focused mainly on children from the settlement,

16 The history and the 20th anniversary of the establishment of the Word of Life in Slovakia are described in the thematic issue of Vitazny żivot, 2015(1).

17 The mission among Gypsies is discussed in the thematic issue of Vitazný żivot, 2002(2).

18 Vitaznýzivot, 2002(2) and my interview with M. Juríček in 2003. See also http://www.etrend.sk/trendarchiv/rok-/cislo-August/centrum-socialnej-prevencie-v-plaveckom-stvrtku-pomaha-romom-zaclenitsa-do-obcianskeho-zivota.html (consulted on 10/08/2015). The sermons of pastor Milan Juríček among the believers in Galanta are freely available at https://www.youtube.com/watch?v=tWjUeIrrAoc (of 20/05/2012, consulted on 10/08/2015), https://www.youtube.com/watch?v=aAa_3FguQKw (not dated, consulted on 10/08/2015) and https://www.youtube.com/watch?v=s6IyLAOEfeM. The latest sermons are simultaneously interpreted into the Romani language https:/www.youtube.com/ watch?v=z2v0loUNpzM (of 08/06/2014, visited on 10/08/2015). 
having launched many different initiatives, including preschool education, tutoring and interest groups. He also reached out to adult Gypsies with his teaching. These years were followed by a period during which the Word of Life withdrew almost completely from Plavecký Štvrtok, and Milan Juríček devoted increased efforts to a Roma assembly that he founded in Galanta. The activities of the Word of Life were later relaunched in Plavecký Štvrtok owing to the work of Pastor Csonka. Today, the Pastor Farkaš, of Gypsy origin, is active in the settlement, and the activities organized by the Word of Life in Plavecký Štvrtok involve around 30-50 Gypsies. ${ }^{19}$ The pastor is familiar with Romani and Hungarian languages, but he teaches in the Slovak language in the local assembly since the mother tongue of local Gypsies is a local dialect of Slovak. ${ }^{20}$

\section{Maranata Christian Mission - Rudňany}

In 2005, Emil Adam, a Czech missionary of Gypsy origin, began to conduct activities among the Gypsies in the Spiš region. He was sent to Eastern Slovakia by the Pentecostal church Christian International Mission of Ostrava. With the help of this church, he managed to create the Maranata assembly. Thanks to the gradual and systematic training of pastors from among the assembly's Gypsy members, the original mission in the municipalities around Spišská Nová Ves (Rudňany, Markušovce and Bystrany) expanded into a number of other locations in the next years (Smižany, Richnava, Poráč, Letanovce and Hranovnica). New assemblies were set up in Poprad, Giraltovce, Humenné and Liptovský Mikuláš, as well as in Sheffield and Peterborough, UK, due to the extensive labor migration of the church members to England. Rudňany is one of those municipalities where Gypsies live in extremely critical conditions. The Gypsy population of Rudnany is 1,700 (around 45\% of the total population), living in several settlements - five residential units (e.g. "Zabíjanec", "Pätorácke", "PRP-čko"), some of them being segregated, others spatially integrated within the municipality. Low-standard social flats have so far been constructed in three parts of the municipality inhabited by the Gypsy population. The prevailing denomination is the Roman Catholic Church. The Pentecostal mission of Emil Adam, known as Maranata Christian Mission,

19 From the author's research report produced under the SIRONA 2010 research.

20 To illustrate the context of Plavecký Štvrtok, it should be noted that the location is specific to a certain degree not only when it comes to the cohabitation of Gypsies and non-Gypsies in the municipality but also Gypsy cohabitation within the Colony. The mutual relationships have been aggravated due to a long-lasting conflict between Gypsy groups in the middle of the Colony, which has resulted in fights and violence several times. In 2001, a committee for tackling the Roma issues was set up in the municipality; for more details, see article http://www.sme.sk/c/176831/v-plaveckom-stvrtku-vytvorilikomisiu-na-riesenie-problemov-romov.html (04/12/2001, consulted on 10/08/2015). 
is officially run as a civic association. It has two main assemblies at present - in Spišská Nová Ves and in Poprad. Even though the missionary activities target primarily the Gypsies, the assembly events are attended by around 20 "white" believers as well, mainly from the Poprad assembly. The estimated total number of converted Gypsies in both assemblies is 1,000. There are around 200 sympathizers of this mission in Rudňany, with 50-60 believers regularly attending church services and other assembly activities. Rudňany thus represents a very strong background for this Pentecostal movement in the Spiš region. Besides regular central Sunday gatherings in Spišská Nová Ves, local services or "small groups" are held during the week in the municipalities in which the mission is present.

Picture 2. Maranata Christian Mission, Sunday Mass in Spišská Nová Ves, 2010. (Author of the photography: Tatiana Podolinská, 2010).

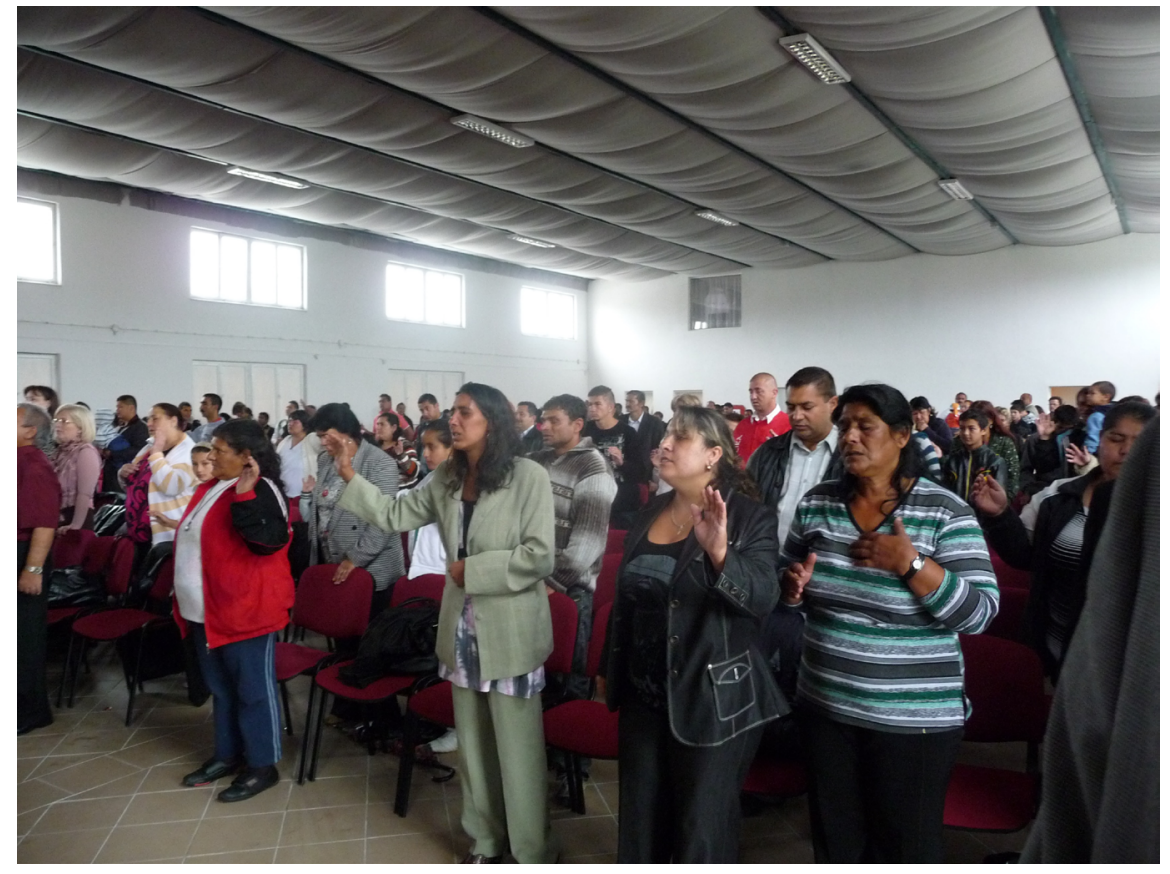

The movement's activities include Biblical teaching. According to the pastor, it is very important for the movement to bring up religious leaders from among its Gypsy members, as they are also expected to set an example to other Gypsy believers. Moral integrity and the ability to provide for themselves and for their family are, according to Emil Adam, important factors in the selection 
of religious leaders from among Gypsy believers. The movement seeks to motivate their members to be active when seeking a job or doing business, to effectively use their finances and to be economically self-sufficient. In addition, the pastor systematically fights against usury, alcoholism, smoking and drugtaking. The pastor preaches in the Czech language, but he motivates his Gypsy adherents and deacons to learn and speak Slovak, in order to overcome segregation and exclusion from the mainstream population. The relationship between the mission and the municipal self-government is considered positive on both sides; the municipality offers the community center premises for free for the purposes of local assembly services. According to the pastor, it is rather an exceptional attitude by the local self-government. Mainly at the beginning of the missions, they mostly faced negative reactions both from the local selfgovernments and local churches. In many parish churches, the priests were said to have rejected carrying out baptisms, marriages or funerals of those Gypsies who were interested in the Maranata mission. The movement and its believers must also fight against the "sectarian" label. ${ }^{21}$ In 2015, the Maranata Christian mission celebrated 10 years of its existence. ${ }^{22}$

\section{Community of Paul the Apostle - Čičava}

The establishment of the Community of Paul the Apostle is the result of several years of successful activities of the Roma Pastoral Centre ("RPC") in Čičava, which conducts missionary activities of the Greek Catholic Church among Gypsies in the region of Vranov nad Toplou. Just like many other churches and religious communities in Slovakia, the Greek Catholic Church also focuses part of its pastoral activities on Gypsy communities. At the same time, the Community of Paul the Apostle confirms the trend of the missionary work of Pentecostal and Charismatic religious organizations among Gypsies. By placing emphasis on the active influence of the Holy Spirit and with its organizational structure (formation of small local groups and lay leaders, payment of church contributions), it can be considered part of the relatively wide group of the Charismatic movement within the Catholic Church.

The Community of Paul the Apostle is a church community created on the basis of the mission of the RPC in Cičava. The center was established in 2005 on the initiative of the Greek Catholic non-Roma priest Martin Mekel, who, having experience in working within the parish churches of

21 Based on the author's report for the purposes of the SIRONA 2010 research. The movement is very active on the internet; see, e.g. https://www.facebook.com/MaranataKrestanskaMisia (consulted on 11/09/2015).

22 See sermon by Emil Adam of 06/06/2015 at http://kmmaranata.sk/video-10-rokov-prace-krestanskejmisie-maranata/ (consulted on 11/09/2015). 
Varhaňovce (2001-2003) and Hlinné (2003-2005), decided to dedicate his time to pastoral work with Gypsies exclusively and independently from the duties of a parish priest. The RPC currently performs pastoral work among Gypsies in a large part of the Vranov nad Toplou district, in particular in the municipalities of Čičava, Sol', Hlinné, Čaklov, Zámutov, Jastrabie n/T and Bystré. ${ }^{23}$ The RPC in Čičava, based on the activities of which the Community of Paul the Apostle was created, is currently the only special mission of the Greek Catholic Church assigned for the pastoral work with Gypsies in Slovakia, independent from local parishes. The Community is run on a relatively autonomous basis within the church, and its activities are covered by a civic association. ${ }^{24}$

The Gypsy population of Čičava, Vranov nad Toplou district, is around 600, which is around $65 \%$ of the total population of the municipality. The Gypsies in the municipality live in two concentrated settlements on two opposite sides of the municipality. Most Gypsies are baptized Greek Catholics, and some of them are members of the Roman Catholic Church as the locally prevailing confession among the majority population of the municipality. Before the start of this pastoral work, any attempts of the Greek Catholic Church to carry out major activities were viewed negatively by the non-Gypsy believers. This was one of the reasons why the Greek Catholic Church did not work systematically with Gypsies before the arrival of Martin Mekel. He began his mission in Čičava in 2005 by being assigned by the Bishop of Prešov, on his own initiative, to work with Gypsies. He has concentrated his missionary activities not only in Čičava but also in the nearby municipalities of Vranov nad Toplou district - a total of 10 municipalities and 15 minor communities. Besides the Community of Paul the Apostle, he is responsible for several other civic associations: the RPC, the Private Leisure Centre, the Hot Team and Slovak Scouting.

The beginnings of the activities of the Pastoral Centre in Čičava were not easy, and the success in the form of the conversion of the first believers came gradually. According to Martin Mekel, this success was due to regular evangelization. At present, the Sunday services organized in the Culture Hall of the Municipal Office building in Čičava are regularly attended by around 80 Gypsies, of which around 50 are directly from Čičava. Martin Mekel holds the view that further expansion of the mission requires the training of new

\footnotetext{
23 Research work and report by L. Hrustičová (Plachá) under SIRONA 2010 research (Archive of the Institute of Ethnology Slovak Academy of Sciences).

24See also: http://mojakomunita.sk/web/pcr-cicava/stretnutia-spap and http://mojakomunita.sk/web/ pcr-cicava/prednasky (consulted on 11/09/2015).
} 
Gypsy leaders directly from the group of believers whenever possible. One of the means for the training of leaders is the Biblical school designed for both adults and the youth. Work with youth and children forms the basis of the Pastoral Centre's activities. Besides regular scouting events and club activities, the center organizes a "mentoring school" for boys and girls each month, serving for youth formation. Young people spend the weekends in the Pastoral Centre, which is an opportunity for Gypsy children and youth to know life outside the settlement. In this way, the Pastoral Centre substitutes, to a certain degree, social community work. Mekel uses inclusivistic pastoral discourse; he respects other denominations and "Roma culture" too. He is Slovak and he preaches in Slovak language, but he speaks Romani language and he promotes the value of Romani language and culture; and he organizes the ecumenical open air gospel festival Romfest on a yearly basis in RPC Garden.

Picture 3. Gospel festival Romfest in Cičava in the garden of the Pastoral Centre, Greek-Catholic open air mass at the end of the festival. (Author of the photography: Tatiana Podolinská, 2013).

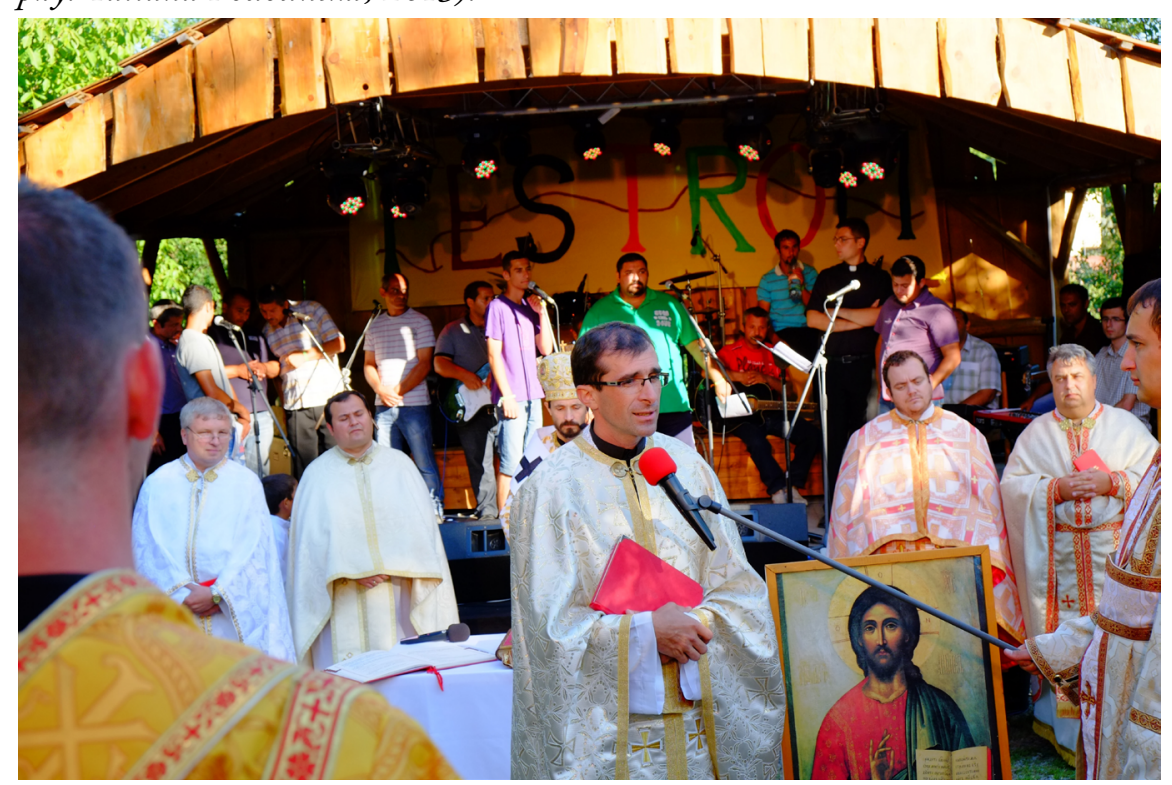

\section{Micro-level: "God has a single colour. We have the same blood!"}

After describing the wider context of the individual denominations within the different locations, I will further focus on the micro-level, i.e. the testimonies 
of the converts ${ }^{25}$ who are actively engaged in the respected assemblies. My research revealed that "being born again", within the individual converts' narratives, means many different things. Converts coming through the socialization within the churches learn how to accommodate their personal experiences into the frame of pastoral discourse and general narrative of conversion as a radical change.

Doing my fieldwork research, I found this sort of classification of people quite typical for nonconverted Gypsies: "It must be always stressed. Because if somebody just says 'People' we do not understand who is meant. So we have to use the names: White-People and We, Cigáni" (Gypsy female nonconvert, Plavecký Štvrtok, 2004).

While in nonconverts' narratives, the categorical dichotomy followed the ethnic/racial boundary marker (Barth 1969) of non-Gypsy and Gypsy, in converts' narratives, the group categorization underwent reconstruction and, as such, followed universalistic conception with the religious boundary marker; more precisely, it was constructed on the basis of "true belief" (to belong to the Pentecostal/Charismatic group or not): "God has a single colour. We have the same heart, and we also have the same bread. We have the same blood" (Gypsy male convert, Plavecký Štvrtok, 2004); "God created us with the same thing, all of us. Blood is said to be divided into groups $-A, B, 0$, but it's always red colour. We only differ in this [in our outward appearance; Tatiana Podolinská or T. P.]." (Gypsy female convert, Plavecký Štvrtok, 2004). In individual testimonies, the impact of general pastoral discourse was clearly visible: "Regarding the non-Roma, he [the pastor; T. P.] also teaches us that They [the White People, T.P.] are people too, just as we are, that we should behave decently, and non-Roma should behave decently towards us, too. He makes no difference between Roma and non-Roma, he makes no difference. He teaches us that we shouldn't be bad with them. The non-Roma. And when someone hurts us, we should speak nicely to him and forgive him, even if it's a non-Roma, we should forgive him. And talk to him nicely. With no anger" (Gypsy male convert Plavecký Śtvrtok, 2004); or "No, it is neither a Rom, nor a Slovak anymore, it's God's child. Because if we're God's children, then he's my brother. Why? Because we have a single parent - it's God. And now, through the relationship which we have with the Lord, we start to live in that relationship, but the one given to us by God was not created by us. Do you understand? And then others would addWhite or Rom, always adding something... in that God's love, we'll start to love each other as brothers and sisters, we don't see each other as white or Gypsy, this

25 I will respect the anonymity of the people I talked to, giving as a background just basic personal information, locality and year. 
would disappear. This is where I saw God within our assembly; when I saw white men speaking and singing Roma and saying 'phrala, bro',, isn't there God's love?... But I can see that the Gospel can change people and does not distinguish between nations. We'll love each other in the way we are, but with the Lord!" (Gypsy male convert, Plavecký Štvrtok, 2015).

Nevertheless, personal interpretation of general pastoral trans-ethnic and trans-social discourse within the individual convert testimonies varied considerably, as well as the intensity of acceptance of the redefined basic classificatory schemes and their trust in the reconceptualized label Rom/a. Summarizing from the narratives collected during the SIRONA 2010 project, there are some interesting points to comment on, as follows:

(1) Out-group hierarchies, intra-ethnic asymmetries and power disbalance

Pentecostal and Charismatic pastors come with a very strong trans-ethnic and trans-social discourse, ${ }^{26}$ which is supposed to perfectly "dissolve" the ethnic and social stigmatization of the "New Roma". With a grain of simplification, based on analyses of individual narratives of three assemblies, I would say, that there is an evident tendency of individual converts not only to rethink and reformulate their individual and group ethnic identity but also out-group hierarchies, positioning and asymmetries of power. In terms of working with ethnicity, nonconverts' pattern of social positioning was Gypsies against Whites (non-Gypsies), with strong disbalance in the terms of hierarchies (in favor of Gypsies) and empowerment (in favor of Whites), whereas after conversion, the pattern is more prone to be (new) Roma alongside other nations. This is not meant to say that Pentecostal converts lose their ethnic sensitivity. The ethnicity is still reflected and perceived as the diversity marker; nevertheless, this "new ethnicity" is "reconceptualized" in terms of liberation and emancipation. To be honest, during my research, I also met some converts who had personal doubts concerning the possibility of acceptance of the reconceptualized label "New Roma" or "New-born Roma" by the mainstream (non-Roma and non-Pentecostal) society: "All tell us, you're the same, just like White People are the same. And I think just one thing: No! This isn't true... It doesn't exist. Because here, in Slovakia, or if I went to the end of the world... Perhaps if I went to see my peers of the same colour, they wouldn't know whether I'm a Rom or a Gypsy, they wouldn't understand what I am. They would take me as I am. But here? Oh! If you're dressed nicely, when you're neat, it's all the same... You're just a Rom!" (Gypsy female convert, Plavecký Štvrtok, 2004). 
(2) Intra-group polarizations and categorizations

In addition to the new categorization of people (Pentecostal believers and nonbelievers), which can cause new polarization in converts within their broader social field, pastors are well aware of the internal intra-group polarizations (social stratifications) within the local Gypsy community or between local Gypsy communities. ${ }^{27,28}$ In spite of the strong trans-social discourse, according to which believers should lose the grounds for taking into account the social and sub-ethnic inter-group stratifications, as all of them are "Brothers and Sisters in Jesus Christ" after the conversion, there are still socially sensitive individual narratives; they feel, at the least, a strong need to emphasize that they do not care anymore about the internal hierarchy of Gypsy groups on the basis of the sub-ethnic, cultural or social code: "We're no more enemies - as we used to be. We're sitting in the same room, talking to each other, taking each other's hands, and jointly praising the Lord!' (Gypsy male convert, Plavecký Štvrtok, 2004). Sometimes they reproduce the pastoral narrative, but they add a grain of doubt by using the conditional time: "T. P.: Are they Wallachians or Rumungris like you? Convert: 'Yes, like us! They're normal. And they would now say: - I make no difference in that you're from Rudnany, the other one is from Zabijenec, not anymore! They're still praising the God, we're all together now, we love each other, though we didn't know and didn't seek each other before, so it's a change, because the pastor also taught us that these people shouldn't make any difference between the poor ones living in huts or those living in big houses... in big villas, there shouldn't be any difference. All should be equal. And this is the basis for us coming together'" (Gypsy female convert, Rudňany, 2014).

As was discovered during the SIRONA 2010 research, at least at the process of establishing of the Pentecostal/Charismatic assembly, the conversion can strengthen local intra- and inter-group polarizations on the basis of the nonacceptance or problematic acceptance of the ethnoreligious category "New Roma" by the remainder of the local population (Gypsy or non-Gypsy) as positive. ${ }^{29}$ Especially in predominantly Roman Catholic regions, the overall

27 "There are many Gypsy groups. You must tell precisely whom you mean. The name of the family. I'd say that all hate each other here. $X X$ hates $Y Y$ and $Z Z$ and these hate $X X$. And all hate white people, just like white people hate them" (female Roma convert; the family names are replaced with XX, YY and ZZ) [the surnames of families were anonymized by T.P.]

28 "They live in suffering, with fights by their own people within the house, with the debts they carry along as a result of their incorrect way of thinking and acting, being afraid of rejection, condemned and accursed by the world and by "believers". In many, curses stretching over generations" (pastor of the Assembly of the Apostolic Church in Rožňava, Vit́azný život, 2002(2): 3).

29 For cases of strengthened polarization and the effects of the multiplication of stigmas using the "sect/ sectarian" label, see Podolinská and Hrustič (2011). 
attitudes towards Pentecostal and Charismatic churches are negative; in the eyes of the mainstream population, these nonregistered churches are reflected as sects, and their adherents thus often suffer double stigmatization (Cigáni) Róm plus sectarian). The local Gypsy population follows this mainstream pattern too. For instance, in Rudňany and Bystrany, I was repeatedly told by nonconvert Gypsies how scared they were after facing the destruction of images and statues of the Virgin Mary, Jesus and crucifixes in public by new converts to the Maranata movement. Plavecký Štvrtok was an exceptionally strong example of the case. After a while, trying to match internal clusters of extended families looking for the roots of deep animosities marked in the internal architecture of the Colony by so-called "fences of war", I recognized the ambiguous role of the movement Word of Life in the deepening of the existing conflict between the various local Gypsy "clans". Soon after the entrance of the movement to the Colony in the second half of the 1990s, it turned into a battle field, divided into convert versus nonconvert sides, both operating with the dualistic notion of the "true God" (on We-Side) and the "Satan" (as the false God of They-Side) addressing the They-Group as sectarians or even occultists (Podolinská 2003).

(3) Effect of out-lifting and the "homeless" people

Following the theory of deprivation, many authors claim that this new sensitiveness and shifts in boundary markers may serve as a kind of "social lifting" and emotional relief from both previous emic-social group polarizations as well as ethnic stigmatizing. Based on my research, I would be careful with giving a quick answer to the very difficult and complex question: why does somebody convert to any religion? In my eyes, it is first of all the question of belief and personal choice. In this instance, the pragmatic benefit of this religious shift is very doubtful, and in many cases, converts face worsening of their previous status by multiplying social and ethnic stigma by a sectarian one. I faced many narratives of converts, who, after being a very active and excited adherent of the local Pentecostal or Charismatic assembly, finally found themselves in a "no-side position", no-man's land, being an outsider in their formerly own world (Gypsy community) and not becoming an insider in the formerly They-world ("white" society): "They are against Us. Both of Them. Cigáni [term for nonconverted, "bad" Gypsies; T. P.] and White People. It is the same. It does not matter whether it is Rom or White. I have just visited one Catholic woman, and it is the same. It is clear; we are not from this world anymore! There is written [in the Bible, T. P.]: You are foreigners, foreigners! And that is how we feel!" (Gypsy female adherent of Pentecostal church Maranata, Hranovnica, 2010). 
This effect of out-lifting and homelessness caused, in the case of Greta, that she finally quit the Word of life in Plavecký Štvrtok after years of being the right hand of the local white pastor: "I would not bear it any longer. This Gypsiness is something you cannot skip from. I was asking myself, who I am, who I am? What should I do? And, you know, the White people always tried to help me, to help Us, Roma. But, I had to ask myself, what do they want to take from me in exchange?... I am still in touch with God, with my personal God, but I am not with them [the Word of Life, T. P. ], anymore..."

\section{Meso-level: "You are Rom and you can be whoever you want!"}

Based on my interviews with five leading pastors from Word of Life, Maranata and Community of Paul the Apostle (two of them are of Gypsy origin) ${ }^{30}$ and being present on various occasions of their preaching during the regular masses, I noticed that they apply a very similar pattern in working with Roma identity and ethnicity. ${ }^{31}$ Their pastoral discourse continuously uses the terms Rom, Roma, Romani, referring to "something" that is not given but permanently happened to be, that is not connected with the past and predefined in a negative or positive way. In their pastoral narratives, they consistently deconstruct the content given classificatory schemes based on ethnicity as taken for granted, ontologically and historically rooted quality embedded in the members of respective groups. They especially preach against the negative self-perception of the (ethnic) label Rom/Roma by Roma themselves and their passivity in turning their social positioning in a positive way. Ethnic sensitivity remains preserved also in the pastoral discourse, insofar as pastors have to cope with the stigmatizing discourse and discriminatory

30 In order to maintain the anonymity of the pastors, I will not address them by name or location in the quotations used in this part of the article.

31 Of course, there are big differences between the respective pastoral discourses given by each pastor individually. All pastors are also determined by the general pastoral discourse within their own respective Church or Mother Congregation. Since the main scope of the article is to find common features, I will not pay attention to specific peculiarities. Just suffice to mention that I was able to observe the connection between the ethnicity of the pastor and the contracultural (contra-previous "Gypsiness") approach. Two pastors of Gypsy origin in my sample were directly preaching against the roots of poverty and pessimism in the "Gypsy soul". In both instances, they used their own personal knowledge of what it means to be raised up and socialized in a Gypsy family and community. In their preaching, they fearlessly touched very sensitive points in a direct way. I would even say that they did not only capitalize on the position "being one of them" (Ripka 2015) but also on their position of "being not one of them", because in both cases, they were not locals. In fact, for the Gypsy adherents, they were attractive for bringing two-sided imageries, the imagery of a successful gypsy traveller, offering the formulas of success for his kin fellows in a manner of strict but kind (spiritual) father. Here, nevertheless, I have to add that the individual charisma of each pastor is crucial because one pastor of Gypsy origin was able to capitalize on his ethnic origin, whereas another, I would say, was not able to successfully skip from the negative box of "Gypsiness" and after years of operating in a problematic community, I found him with clear signs of the burnt-out syndrome. 
practices in Slovakia. Pastors that I was in contact with described ethnic groups in terms of diversity and equality: "We are all very different, brothers and sisters, different races, nations, cultures, musician, mathematician, physicist, poor, rich... What unites us is the desire to be with the Lord, and this desire makes us equal" (quotation from the journal of Word of Life, namely Vitazný żivot 2002(2): 8) or "In towns where we, Gadje, live together with Roma, I'd like to see a local church where both ethnic groups would feel accepted and loved and where they would serve each other (...) In South Africa... they managed... to create a church of white and black men... Shall we manage to achieve something similar in Slovakia?" (Pastor of the Word of Life Int., Bratislava, journal Vitazný život, 2002(2): 2).

A comparative analysis of the three Pentecostal and Charismatic assemblies brought me to a scheme used by them in an almost uniform manner (with some difference in emphasis according to the situation and charisma of each pastor). ${ }^{32}$ The particular procedure is derived from the perception of conversion as radical change. I will seek to describe it by means of quotations from sermons, individual interviews, official websites of the studied assemblies, as well as printed and visual media forming part of their production. As mentioned earlier, in their pastoral discourse, pastors systematically "untie"/"lift out" the members of their assemblies not only from their personal but also group history. After the perfect untying"/"out-lifting" from the history of their personal lives and of their original group (Roma/Gypsies), they try to accommodate converts into a new category of humanity. In this category, a Rom remains a Rom, but the content of his/her "Romahood" fills with radically new (religious) content. Nevertheless, the particular content of the personal vision and the trajectory of the "Romahood" are not predefined and are up to the free will of the individual who becomes the (new, reborn) Roma.

Specifically, during the process of reconstruction within the pastoral discourse, we would recognize the following four steps: (1) emptying the original content of label Rom/Roma, (2) releasing the convert from original ties and networks (mainly of primary nature), (3) tying the convert through new bonds and secondary or hybrid networks ${ }^{33}$ to a new institution (congregation/church) and

\footnotetext{
32 On the question of using the Romani language during the masses, for instance, I cannot confirm more frequent usage of Romani language by the pastors of Gypsy origin. Two leading pastors of Gypsy origin were intentionally using the Slovak/Czech language as the primary language of communication and spreading Evangelism: "In the language there is hidden the navigation of life. I am asking my Romani deacons: How do you want to be a good pastor if you do not know to teach in the Slovak language? How do you want to spread the Word, if you do not know the language?"

33 Primary networks are formed by family ties, while secondary networks are built on the basis of professional and interest types. Hybrid ties are defined as secondary ties whose structure or meaning evoke or substitute the inherent primary ties (for more information, see Podolinská and Hrustič 2011).
} 
(4) creative filling of the label Rom/Roma with free content according to new rules (authority and the Bible's moral code).

(1) To be a "New (born) Rom" means to reject Old Rom and the old perception of Gypsiness in order to accept and internalize the new concept of Romahood. "You are drinking, smoking, beating your wife and children, you have no idea of what financing of family means, you have no vision for you and for your kids, you have poor self-esteem, you are passively waiting if somebody does something instead of you and you believe that this is your destiny?! Wake up! Do not repeat the pattern of life of your parents and neighbours! This is not Romahood!!!" ${ }^{34}$ (Roma ${ }^{35}$ pastor).

What is important in this pastoral discourse is rejecting both the heterostereotypes and auto-stereotypes as inevitable elements of Roma culture. Since we focus on the level of a religious group, this primarily concerns the previous way of practicing belief and traditional Gypsy (folk) religiousness. The previous way of religious life (formal Catholicism with elements of majority folk belief, type of domestic religiousness without a religious authority and without religious holidays, with elements of magic practices, healing, divination, strong belief in the spirits of the deceased and worshipping of statues and images of the saints, the Virgin Mary and Jesus Christ, oaths, "bewitching", "cursing" ${ }^{36}$ and incorrect interpretation of the Virgin Mary as a divine, holy person $)^{37}$ is often denominated in the pastoral discourse with the terms "Satanism" and "occultism", the worshipping of the false one ("dead God") and "idolatry" (the worshipping of images and statues). Converts must unconditionally give up these elements of religiousness, inherited and learnt within the Gypsy community. ${ }^{38}$ Yet, the previous (incorrect) belief and form of religiousness form part of the previously "incorrectly" defined way of (Roma) life. Pastors point out and directly negate the previous way of life and the unwritten rules of socialization within Gypsy communities:

The following extract from an interview with a Pentecostal pastor shows his strategy aimed at interpreting the elements that are, as a stereotype, perceived as "Roma" and, instead, to offer their more general presence "within each nation":

34 In order to maintain the anonymity of pastors, I will not indicate the locality in quotations used in this part of the study.

35 Pastors of Gypsy origin address themselves proudly as "Roma", promoting thus public usage of this reconceptualized ethnolabel.

36 For more details, see Podolinská 2009a, b.

37 For more details, see Podolinská 2014b.

38 This often happens publicly and in an ostentatious manner: destructions of statues and burning of "holy pictures" at public places within locations inhabited by Gypsies. 
"What I mean is that-just like our Roma-Slovaks and Hungarians, in fact, do the same... drink alcohol, smoke, take drugs... or... everyone does that... people in all nations do that... I say (...) I do it only because God wishes it, and I believe in one thing - that God wishes it, just as he visits many nations, Russia or Sweden, Hungary, and we could also hear about the great awakening in Africa and India and at many other places... I believe that God wants to visit the Roma nation, as well" (Interview with a Roma pastor).

After the first step - the radical negation - pastors move to the second step:

(2) The emptying of the original content of "Romahood" and the untying of converts from previous (predominantly primary) bonds. Pastors repeatedly emphasize the moment of conversion or baptism as moment "zero", as the point of the birth of new man/woman, as the point of a new beginning. Change is possible and change is visible. Pastors use many concrete positive examples from the surroundings of converts, usually offering the example of themselves, while repeating to the converts: "You're a new man, a new woman!" The condition, however, is the giving up of the original way of life and the rejection of the local habitus of the Roma community in which they lived and grew up.

"Today, our children or their children no more follow the habits and traditions of their fathers - where, simply said, dad comes home drunk, beats mom, and they've got nothing to eat - now, they set an example, take the Bible and pray at home... They know that when they have a problem, they can pray and God would show them the solution.... That's a big turn!" (Interview with a pastor); or "Don't trust your mother and your grandmother when they tell you that you're nobody! That you're a Rom and that you'll be nothing! You can be whoever you wish to be, Roma can be whoever they want be. Wake up and start to be Somebody!" (Interview with a Roma pastor).

Especially in one Roma pastor's preaching, this untying and "uprooting" out of Gypsy culture as conditio sine qua non was strongly present and his imagery on Gypsy culture as a platform that produces and reproduces the circle of stereotypes and poverty has got very direct contours: "It is very common among Roma: cursing, cursing, cursing by each word. Roma songs are also a curse. They come not only from Roma culture, but directly from the roots of that poverty. You wouldn't find there a single word that would sound perfect; you can only hear about death, poverty, sadness... and about love, but love in those songs is very painful, there's never... joy! Nevertheless, Roma can be cheerful, they can dance, be wild... But they are immersed in it, and even the rudder of their language is constantly steered in the same circle all the time, generation after generation, generation after generation. (...) My generation got a completely different rudder, 
I show a different direction to my children and tell them: you can be whoever you want, you can improve it, you're capable of doing it, you're not ordinary, you can do it"! (Interview with a Roma pastor); or "We teach them the following: stop telling your children - for example - stop telling your children that they would be nobody! I tell them, motivate them! Just tell them that they can stand up and be whoever they wish to be! This takes some time, but they can indeed be whoever! They can do it... (...) We believe that power is in the words. Those habits are the rudder of life; if you steer it in that direction, you would arrive where you want to arrive, and so we teach them how to steer...!" (Interview with a Roma pastor).

(3) As the third step of the systematic reconstruction of the content of the label Rom/a, pastors offer believers a new value and ethnic framework for this category (depending on the religious code) and tie the "untied" believers to new social networks and institutions. They offer them a new set of the morale and values as well as a system of written rules (the Bible), while tying the convert to institutions (church/assembly) through a network of secondary nature. Pentecostal and Charismatic assemblies offer social statuses with positive prestige, they offer social ladders that are independent of the majority (a sophisticated system within which talented or enthusiastic candidates can ascend: group leader, praiser, deacon, pastor, preacher, apostle, etc.). They offer various functions to women, too: leader of a women's or children's group; in some cases, women as full-fledged pastors (within the Word of Life). At the same time, and this should be emphasized here, they do not offer strictly predefined contents of the category "Rom/a": “... and so, God gave us free will. You must decide as you wish. You must live your own life. If you want to be loved, you must start with loving yourself" (Interview with a pastor).

As mentioned previously, after the untying and rejection of personal and group history, the individual is prepared, at the micro-level, to actively fill the content of the "Romahood" with individual content. In line with the moral set of the community and its written rules (the Bible), it is not necessary to repudiate all before-conversion cultural idioms; vice versa, the Roma language, dance, food, love for children, the way of intensive family communication and life, informal primary bonds, all this can become a constitutive element of the new form of "Romahood". This vision and its actual living do not require a historic version of the origins of the Roma nation, there is no need to build identity on "owning a territory, on won struggles and national heroes..." (Excerpt from interview with a pastor).

The first two steps (emptying and releasing) seek to negate the convert's previous way of life and behavior and to break them away from the "old world" discourse/narrative. The world of the traditional Gypsy community in Slovakia 
is viewed in the pastoral discourse as an environment that reproduces the cycle of poverty and has low social self-confidence; literally, as an environment that passes poverty and social complexes down from the grandparents' and parents' generations to the children's generation. This "traditional" discourse/narrative then objectively fixes the unfavorable or dependent social position. We could talk about an "incarcerating discourse" and "incarcerating story". Pastors seek to programmatically break this traditional narrative cycle through negation, emptying and untying.

The other two steps (tying and filling) focus rather on a positive projection of the new content of "Romahood" by offering positive narrations, a positive self-image and a discourse that motivates the emancipation of social selfconfidence and the searching of new positions within the social field. Pastors do not get satisfied with a vision within the field of the Roma community but encourage converts to take positions within a wider social space predominantly occupied by the majority.

\section{Back to ethnicity and nation}

In the moment that we reach the level of the need or ambition to begin to play the role of the "partner" (decent actor) within the majority space, where prestige as seen by the majority is important (for instance, due to the ambition to obtain a share in power), the construction of the category "Rom/a" and the construction of the category "Roma nation" begins to acquire meaning and importance. At this level, we then face the problem of failing to meet the common definitions of the nation. Yet, the majority does require the fulfilment of at least some of the points of the traditional definition due to its own historically embedded expectations. ${ }^{39}$

If we use the traditional definitions of the nation by enumerating the elements that jointly constitute a nation or an ethnic group (see, for instance, Hroch ed. [2003] and Hroch [2015]), in the case of Gypsies, we arrive at the metalevel of this term and face serious problems with regard to the key points of these definitions, i.e. the "Roma nation" consists of different heterogeneous ethnic groups without an original state, without their own territory, without a common language, without a single religion, without single habits and traditions, without the awareness of single collective identity, and without collective cultural traditions and historical memory.

\footnotetext{
39 It is up to Roma leaders and scientists to suggest more flexible definitions of modern nations and nationalities. For instance, Paul James defines nation as an abstract community (in Hroch [ed.] 2003, 392); Ernest Renan claims that the nation is a spiritual principle created by the common ownership of memories and by the consent of individuals to their common life (Hroch [ed.] 2003, 33).
} 
The main problem in the ethnogenesis of the Roma nation is that it runs under the reflexive modernity conditions but the requirements placed on it remain fixed in premodernity and solid modernity. ${ }^{40}$ In global societies, however, these traditional ethnic constitution elements are becoming less clearly defined, replaceable and flexible. The majority of requirements for a unique character of Roma culture, language and so on as the constitutive elements of Roma identity in the 21 st century can therefore be clearly designated as irrelevant calques of the solid modernity from the beginning of the 20th century.

Pastors have to find their way in this process. When it comes to the definition of the collective ethnic category "Roma nation", Pentecostal and Charismatic pastors use the conversion vocabulary and the concept of "rebirth" and "awakening" of the Roma nation at the national and global levels.

On this platform, they (in some contradiction to the previous, individual and local community levels) raise topics with "nationalist rhetoric" and a historicizing context: Roma as a persecuted nation (parallels with the people of Israel and Jews are quite common), Roma as God's chosen nation, Roma as a nation with Indian roots, etc. Nevertheless, in their constructions, the topic of continuity is not the object of capitalizing. More prevalent and topical is the point of (radical) change: change of the role of the Roma nation under God's influence, unification of Roma groups as God's nation and change at the leading social positions (in line with the Biblical principle "the last will be the first").

In this context, the reconceptualization of the "New Roma" identity within the Pentecostal and Charismatic pastoral discourse in Slovakia is aiming intentionally at uprooting Gypsies from the "Cigáni story narrative". The previous group ethnic narrative is considered to be a platform for reproduction of self-stigmatization, self-underestimation and underclass status. Cutting out of this narrative is aimed at enabling the New Roma to leave their old, historically disadvantaged and stigmatized positions and to adopt new, socially and personally more favorable positions in the contemporary world.

Back to the general theories in ethnic and racial studies, Pentecostal and Charismatic pastors with their concept of "New Roma" and "Roma nation" are implicitly operationalizing the idea of "new ethnicities" (Hall 1996), which are seen as a cultural product, as a way of day-to-day living and a way of talking about experience. Pastors try to "relocate" their adherents into the positively reconceptualized identity of "New Roma", "out of a particular history ..., out of a particular culture" (Hall 1996, 447). As far as

40 On the concepts of modernity, see Bauman (2000) and Beck (2006). 
Pentecostalism being one of the most important religions among the European Roma people is considered, the strong emphasis on ethnic and emancipative agendas is something that emerges urgently from their pastoral praxis facing the social ethnically stigmatizing practices. In looking for gains in social interactions within the home state and mainstream Slovak/White population, pastors attempt to redefine the formerly stigmatizing group identity of their Gypsy adherents. Recognizing the negatively perceived ethnic label Roma as the main obstacle in getting access to the sources of gains and power, they attempt to reconstruct the basic classificatory schemes based on ethnicity and they introduce the concept of "New Roma" with positive connotations based on moral quality. In doing so, they refuse to uncritically adopt the categories of existing ethnopolitical practice and reproduce them in their pastoral discourse.

Manuela Cantón-Delgado traces this phenomenon in terms of "contemporary process of religious and ethnic innovation $(2017,77)$. The pastors are the engines and propagators of this redefined Roma identity, who reproduce singularity without recourse not only to the common ethnopolitical discourse but also to the usual anthropological and Romani studies discourse constructing the Roma identity on the bases of land and territory, shared unwritten rules, cultural customs and language, a shared past or internal unity or cohesiveness ${ }^{41}$ (see also Gay y Blasco 2011, 445).

\section{Conclusions}

The comparative analysis of the practical ways of work with ethnicity within the pastoral discourses of three selected denominations in Slovakia has shown that it is constructed as an ahistorical category of practice, which is intentionally largely ethnically emptied and creatively filled with specific content according to the life goals and paths of particular users either at the individual level or at the community level in line with the creed of good, moral, useful and decent life (of a Christian= Human= Rom).

In spite of the strong trans-social and trans-ethnic discourse, according to which believers should lose the reason for taking into account the internal social group stratifications, the research revealed that they still remain

\footnotetext{
41 According to M. Cantón-Delgado (2017, 83), the Pentecostal movement among Spanish gypsies, opposed to Rom identity Gypsy activism, does not reduce Gypsy society to an "ethnic minority" among others, but rather to a moral quality that is common to converted and nonconverted Gypsies and superior to that of the non-Gypsy world. In my Slovak fieldwork research, I could not confirm such a pattern: religious belonging, commitment and moral quality were superior to those of any ethnicity, the Roma ethnic identity was reconstructed within the religious group and the identity of the convert Roma and non-Roma within the group was superior to the identity of the nonconvert.
} 
ethnically and socially sensitive. An important change in this context is, however, that the previous paradigm Gypsies versus Whites turns, after conversion, into the paradigm Roma alongside other nations. This fundamentally changes the positional way of defining themselves in relation to others. The New Rom is primarily the negation of the Old Gypsy, not of the "White"/Gadjo.

When exploring the common features of the practical (re)construction of the Roma identity and ethnicity within the conversion narrative and the pastoral discourse, it is possible to distinguish four common steps: (1) the emptying and negation of the original content of the label Gypsy/Rom; (2) the release of the converts from their previous bonds and networks (of mainly primary nature); (3) the tying of the converts to a new institution (church/ congregation) through secondary or hybrid networks; and (4) creative filling of the label New Roma with content according to the convert's personal vision in line with the new set of rules and values (the moral code of the Bible).

Based on individual converts' testimonies, they are familiar with and reproduce the reconstructed classificatory schemes of people, and they also actively reframe the world as a place with rethought hierarchies and redefined balance of power. Conversion thus can be considered to be not only the religious turning point but also the crucial point of turn from passive to active modus operandi in the world. Starting with active deconstruction of the negative self- and group image, to the active deconstruction of the idea of "unfair world" into which one is born and stuck in to live and die, to the active and creative construction of a positive self-image as a moral and good individual, continuing with the good image of the community of which I am a member and good part. In the course of my research, I found the pastors not only in the role of "grand deconstructers" but, what is even more interesting from my scientific point of view, in the role of grand constructers, or even engineers, mentors and tutors of this ethnoreligious innovation based on positive construction of the label Rom/a primarily on moral (not ethnic and racial) principles.

The way in which Pentecostal and Charismatic pastors positively reconstruct, reconceptualize and negotiate the Roma identity at the individual, group, collective and national levels is largely beyond the traditional (modern) perception of the construction of ethnic identities on the basis of constitutive historical elements of origin, country, language, culture, etc. The researched Pentecostal and Charismatic movements have "untied" themselves from the definition of Roma identity, the practical application of which brings mainly disadvantaged social positions and prestigmatized labels to the members of the group designated in this way. The concept of "New Roma" breaks away 
with the past in terms of its programmes and talks about a new, historically unburdened present and an equal future. Given the absence of support and the systematic creation of a positive picture of Roma at the macro-level in Slovakia, it is more appropriate to view this phenomenon as internal dynamism of Roma and their active endeavors to find a decent human status while retaining the "Roma face", thus promoting cultural diversity and pluralism of identities within the home state.

\section{References}

Acton, Thomas. 2004. "Modernity, culture and "Gypsies”. In: N. Saul, S. Tebbutt (eds.), The Role of the Romanies. Images and Counter-images of "Gypsies". Liverpool: Liverpool University Press, 98-116.

Anderson, Benedict. 1983. Imagined Communities. London: Verso.

Bačová, Viera. 1998. "The Construction of National Identity - on Primordialism and Instrumentalism”. Human Affairs 8(1): 29-43.

Barth, Frederik (ed.) 1969. Ethnic Groups and Boundaries. The Social Organisation of Cultural Difference. London: Little, Brown.

Bauman, Zygmunt. 2000. Liquid Modernity. Cambridge: Polity Press.

Beck, Ulrich. 2006. The Risk Society: Towards a New Modernity. Barcelona: Paidos.

Brubaker, Rogers. 2002. "Ethnicity without groups." Archives de Sociologie XLIII(2): 163-189.

-. 2014. "Beyond ethnicity." Ethnic and Racial Studies 37(5): 804-808.

Cantón-Delgado, Manuela. 2010. "Gypsy Pentecostalism, ethnopolitical uses and construction of belonging in the south of Spain.” Social Compass 57(2): 253-267.

-_-_-_-_-_-_-_. 2017. "Gypsy leadership, cohesion and social memory in the Evangelical Church of Philadelphia." Social Compass 64(1): 76-91.

Census 2011 (Census of People, Houses and Inhabitants) = Sčitanie ludí, domov a obyvatelov 2011

SIRONA 2010 = Archive of Institute of Ethnology SAS of qualitative and mapping part of research titled Social inclusion of Roma in Slovakia via religious way ("Sociálna inklúzia Rómov náboženskou cestou”, acronym SIRONA 2010)

Eriksen, Thomas Hylland. 1991. "Ethnicity versus Nationalism”. Journal of Peace Research 28(3): 263-278. Peace Research (32): 427-436.

Gay y Blasco, Paloma. 1999. Gypsies in Madrid: Sex, Gender and the Performance of Identity. Oxford: Berg Publishers.

2011. "Agata's story. Singular lives and the reach of the Gitano law." Journal of the Royal Anthropological Institute (14): 445-461.

Gay y Blasco, Paloma (2012). "Gender and Pentecostalism among the gitanos of Madrid. Combining approaches.” Romani Studies 5, 22(1): 1-18. 
Hall, Stuart. 1996. "New ethnicities." In: D. Morley, K.-H. Chen (eds.), Stuart Hall critical dialogues in cultural studies. London: Routledge, p. 440-449.

Hroch, Miroslav (ed.) 2003. Pohledy na národ a naciolinalizmus. Praha: SLON.

Hroch, Miroslav. 2015. European Nations: Explaining Their Formation. London: Verso.

Hrustič, Tomáš. 2015. "Záleží na nás ako sa dohodneme”. Prehlad rómskej politickej participácie na Slovensku (1990-2014). In: T. Podolinská, T. Hrustič (eds.), Čierno-biele svety. Rómovia v majoritnej spoločnosti. Bratislava: VEDA, 104-142.

Hrustičová (Plachá), Ludmila. (s.d.) Research report produced under the SIRONA 2010 (Archive of the Institute of Ethnology Slovak Academy of Sciences).

Krekovičová, Eva. 2015. “Komická figúrka Róma na Slovensku v premenách času. Na príklade anekdot a karikatúr." In: T. Podolinská, T. Hrustič (eds.), Čierno-biele svety. Rómovia v majoritnej spoločnosti. Bratislava: VEDA, 398-415.

Ladányi, János \& Szelényi, Iván. 2003. "Historical variations in inter-ethnic relations: Toward a social history of Roma in Csenyéte, 1857-2000.” Romani Studies 5, 13(1):1-51.

Liégeois, Jean Pierre. 1986. Gypsies. An illustrated history. London: Al Saqi Books.

Mann, Arne B. 2015. “Etnické stereotypy ako zdroje vtipov o Rómoch.” In: T. Podolinská, T. Hrustič (eds.), Čierno-biele svety. Rómovia v majoritnej spoločnosti. Bratislava: VEDA, 438-479.

Marushiakova, Elena \& Popov, Vesselin (2013).” Gypsy groups in Eastern Europe: Ethnonyms vs. professionyms.” Romani Studies 5, 23(1): 61-82.

Marushiakova, Elena \& Popov, Vesselin. 2015. "Vplyv orientalizmu vo vede a v politike na spolunažívanie Rómov s majoritnou spoločnostou.” In: T. Podolinská, T. Hrustič (eds.), Čierno-biele svety. Rómovia v majoritnej spoločnosti na Slovensku. Bratislava: VEDA, 60-83.

Marušiaková, Jelena \& Popov, Vesselin (eds.) 2016. Roma culture: Myths and realities. Roma series, Vol. 3. Munich: Lincom Academic Publishers.

Matras, Yaron. 2004. "The Role of Language in Mystifying and Demystifying Gypsy Identity.” In: N. Saul, S. Tebutt (eds.), The Role of the Romanies: Images and Counterimages of 'Gypsies'/Romanies in European Cultures. Liverpool: Liverpool University Press.

Mušinka,Alexander, Matlovičová, Kvetoslava (2015). “Atlas rómskych komunít na Slovensku 2013 ako pramenná databáza pre analýzu situácie Rómov na Slovensku a jeho potenciál pre d’alšie výskumy. In: T. Podolinská, T. Hrustič (eds.), Čierno-biele svety. Rómovia v majoritnej spoločnosti. Bratislava: VEDA, 224-246.

Panczová, Zuzana. 2015. “Obrazy Žida a Róma v humoristicko-satirickom časopise.” In: T. Podolinská, T. Hrustič (eds.), Čierno-biele svety. Rómovia v majoritnej spoločnosti. Bratislava: VEDA, p. 416-436.

Podolinská, Tatiana. 2003. "Boh alebo Satan? Úloha nového náboženského hnutia Slovo života v polarizácii rómskej kolónie v Plaveckom Štvrtku. Slovenský národopis 51(1): 4-3.

2009a. „Nová“ rómska duchovná identita. Charizmatické hnutia medzi Rómami na Slo- vensku. In: G. Kiliánová, E. Kowalská, E. Krekovičová (eds.), $M y$ a ti druhi. Konstrukcie a transformácie kolektivnych identit $v$ modernej spoločnosti. Región strednej Európy. Bratislava: VEDA, 175-216. 
.2009b. Úvod. „Ako zrnko piesku v mori“. Konštrukcia náboženskej identity menšinových a spoločensky stigmatizovaných skupín. In: G. Kiliánová, E. Kowalská, E. Krekovičová (eds.), My a ti druhi. Konštrukcie a transformácie kolektivnych identit v modernej spoločnosti. Región strednej Európy. Bratislava: VEDA, p. 139-143.

2011. "Non-traditional Way of Social Inclusion of Romanies in Slovakia. Pentecostal Case.” In: A. Barszewska, P. Lehel (eds.), Integrating minorities: traditional communities and modernization. Cluj-Napoca: Kriterion, 161-174.

2014a. "Whose Mary? The Virgin Mary as an ethnic, cultural and religious marker among the Roma in Slovakia." In: A. Halemba (ed.), Gebrochene Kontinuitäten. Transnationalität in den Erinnerungskulturen Ostmitteleuropas im 20. Jahrhundert. Köln, Wien, Weimar: Böhlau Verlag GmbH £ Cie, 146-165.

2014b. "Questioning the Theory of Deprivation: Pentecostal Roma in

Slovakia.” In: D. Thurfjell; A. Marsh. (eds.). Romani Pentecostalism: Gypsies and Charismatic Christianity. Frankfurt am Main: Peter Lang Academic Research, 89-107.

2017. "Roma in Slovakia - Silent and Invisible Minority. (Social Networking and Pastoral Pentecostal Discourse as a case of giving voice and positive visibility)." Slovak Ethnology/Slovenský národopis 65(2):135-157.

Podolinská, Tatiana \& Hrustič, Tomáš. 2011. Religion as a Path to Change. Bratislava: Fridrich Ebert Stiftung.

Ripka, Štěpán. 2015. "Being 'one of them': Hierarchy and institutionalization of charisma of an ethnic pastor in a Romani congregation." Social Compass 62(2): 147-158.

Stewart, Michael. 1997. The Time of the Gypsies. Oxford: Westview Press.

Stewart, Michael. 2013. "Roma and Gypsy 'Ethnicity' as a Subject of Anthropological Inquiry.” Annual Review of Anthropology 42(1): 415-432.

Tremlett, Annabel. 2009. "Bringing hybridity to heterogeneity in Romani Studies." Romani Studies 5, 19(2): 147-168.

Vašečka, Michal. 1999. "Rómovia.” In: G. Mesežnikov, M. Ivantyšyn (eds.), Slovensko 19981999. Súhrnná správa o stave spoločnosti. Bratislava: IVO.

Vitazný život 2002, 2015

Willems, Wim. 1997. In search of the true Gypsy. From enlightenment to final solution. London: Frank Cass.

Williams, Patrick. 2003. Gypsy world: the silence of the living and the voices of the dead. Chicago: University of Chicago Press. 